\title{
Chemically Modified Uridine Molecules Incorporating Acyl Residues to Enhance Antibacterial and Cytotoxic Activities
}

\author{
Sarkar M. A. Kawsar ${ }^{1}$, Hamida A. Ara1, Sheikh Aftab Uddin², Mohammed K. Hossain ${ }^{3}$, \\ Shagir A. Chowdhury', Abul F. M. Sanaullah', Mohammad A. Manchur", Imtiaj Hasan', \\ Yukiko Ogawa6, Yuki Fujii ${ }^{6}$, Yasuhiro Koides, Yasuhiro Ozeki ${ }^{5}$ \\ ${ }^{1}$ Laboratory of Carbohydrate and Protein Chemistry, Department of Chemistry, Faculty of Science, University of \\ Chittagong, Chittagong, Bangladesh \\ ${ }^{2}$ The Institute of Marine Science, Faculty of Science, University of Chittagong, Chittagong, Bangladesh \\ ${ }^{3}$ Department of Pharmacy, Faculty of Biological Science, University of Chittagong, Chittagong, Bangladesh \\ ${ }^{4}$ Department of Microbiology, Faculty of Biological Science, University of Chittagong, Chittagong, Bangladesh \\ ${ }^{5}$ Laboratory of Glycobiology and Marine Biochemistry, Department of Life and Environmental System Science, \\ Graduate School of NanoBio Sciences, Yokohama City University, Yokohama, Japan \\ ${ }^{6}$ Divisions of Microbiology, Graduate School of Pharmaceutical Science, Nagasaki International University, \\ Nagasaki, Japan \\ Email: "akawsarabe@yahoo.com
}

Received 10 November 2015; accepted 1 December 2015; published 4 December 2015

Copyright ( 2015 by authors and Scientific Research Publishing Inc.

This work is licensed under the Creative Commons Attribution International License (CC BY).

http://creativecommons.org/licenses/by/4.0/

(c) (i) Open Access

\section{Abstract}

A new $\mathrm{N}$-acetylsulfanilylation series of uridine have been synthesized in good yield using direct acylation method and afforded the $5^{\prime}-O-N$-acetylsulfanilyluridine. In order to obtain newer products, the $5^{\prime}-\mathrm{O}-\mathrm{N}$-acetylsulfanilyluridine derivative was further transformed to a series of $2^{\prime}, 3^{\prime}$-di- $O$ acyl derivatives containing a wide variety of functionalities in a single molecular framework. The chemical structures of the newly synthesized compounds were confirmed on the basis of their FTIR, ${ }^{1} \mathrm{H}$-NMR spectroscopy, physicochemical properties and elemental analysis. All the synthesized uridine derivatives were tested for their in vitro antibacterial activity against six human pathogenic bacterial strains and for comparison standard antibiotic Ampicillin was also determined. The study revealed that the selectively acylated derivatives $5^{\prime}-\mathrm{O}-\mathrm{N}$-acetylsulfanilyl-2', $3^{\prime}$-di-O-lauroyluridine and $5^{\prime}-\mathrm{O}-\mathrm{N}$-acetylsulfanilyl-2',3'-di-O-pivaloyluridine showed highest inhibition against Staphylococcus aureus and Bacillus cereus, respectively. We also observed that the introduction of hexanoyl, decanoyl, lauroyl, myristoyl and pivaloyl groups, the antibacterial functionality of the compound uridine increases. Another noteworthy observation was that the uridine derivatives

${ }^{*}$ Corresponding author.

How to cite this paper: Kawsar, S.M.A., et al. (2015) Chemically Modified Uridine Molecules Incorporating Acyl Residues to Enhance Antibacterial and Cytotoxic Activities. International Journal of Organic Chemistry, 5, 232-245.

http://dx.doi.org/10.4236/ijoc.2015.54023 
were found comparatively more effective against Gram-positive microorganisms than those of Gram-negative microorganisms. In addition, the test chemicals were also tested for cytotoxicity by brine shrimp lethality bioassay and compounds showed different rate mortality with different concentrations.

\section{Keywords}

\section{Uridine, Synthesis, Structure, Spectroscopy, Antibacterial, Cytotoxicity}

\section{Introduction}

Nucleosides are glycosylamines consisting of a nucleobase (i.e., nitrogeneous base) which $\beta$-glycosidic bonded to a sugar (ribose or deoxyribose) and the nitrogen-containing compound is either a pyrimidine base (cytosine, thymine or uracil) or a purine base (adenine or guanine). When nucleoside attached with one or more phosphate groups at the C-5' is called a nucleotide. Nucleotide derivatives are necessary for life, as they are building blocks of nucleic acids and have thousands of other roles in cell metabolism and regulation. Nucleosides are required for DNA and RNA synthesis, and the nucleoside adenosine has a function in a variety of signaling processes [1]. In medicine, several nucleoside analogues are used as antiviral or anticancer agents [2].

Uridine (1) (Figure 1) is a molecule (known as nucleoside) that is formed when uracil is attached to a ribose ring via $\beta$ - $\mathrm{N}_{1}$-glycosidic bond. Uridine is one of the four basic components of robonucleic acid (RNA). Upon digestion of foods containing RNA, uridine is released from RNA and is absorbed intact in the gut. Uridine is found in sugarcane, tomatos, broccoli, liver, pancreas etc. Uridine has anti depression activity, asthmatic airway inflammation, hepatocyte proliferation [3] [4].

Infectious diseases worldwide have been known to be a cause of morbidity, disability and mortality. Approximately 15 million people die each year due to infectious diseases-nearly all live in developing countries [5]. Indiscriminate and unconcerned use of antibiotics has led to increased microbial resistance. Consequently, newer agents have been brought in at increased economic costs to the patient but they too have become inefficacious in due course and pose worldwide a great threat to human health. So, noble, emerging and re-emerging infectious diseases have become a focus for the development of new cost-effective drug in both developed and developing countries. So, the finding of new drug is very important for the treatment.

Selective acylation is very important in the field of nucleoside chemistry because of its usefulness for the synthesis of biologically active products. During the last few years, many workers have investigated selective acylation and alkylation of hydroxyl groups of the carbohydrate moieties of nucleosides and nucleotides using various methods [6]-[8]. Different methods for acylation of carbohydrates and nucleosides have so far been developed and employed successfully [9] [10]. Of these, direct method has been found to be the most encouraging method for acylation of carbohydrates and nucleosides [11].

From literature survey revealed that a large number of biologically active compounds possess aromatic and heteroaromatic nucleus and acyl substituents [12] [13]. It is also known that, if an active nucleus is linked to another<smiles>O=c1ccn(C2OC(CO)C(O)C2O)c(=O)[nH]1</smiles>

Figure 1. Uridine (1). 
nucleus, the resulting molecule may possess greater potential for biological activity [14]. The benzene and substituted benzene nuclei play important role as common denominator of various biological activities [15]. Results of an ongoing research work on selective acylation of carbohydrates [16] [17] and nucleosides [18] [19] and also evaluation of antimicrobial activities reveal that in many cases the combination of two or more aromatic or heteroaromatic nuclei [14]. It is also found that nitrogen, sulfur and halogen containing substitution products showed marked antimicrobial activities i.e., enhance the biological activity of the parent compound [20]-[25].

Encouraged by literature reports and our own findings, we synthesized a series of uridine derivatives (Scheme 1) deliberately incorporating a wide variety of probable biologically active components to the ribose moiety. Antibacterial screening of these compounds was carried out using a variety of bacterial strains and cytotoxicity test was also performed by brine shrimp lethality bioassay and the results are reported here as first time.

\section{Results and Discussion}

\subsection{Chemistry}

The objective of the present research work reported in this paper was to perform regioselective $N$-acetylsulfanilylation of uridine (1) using the direct method (Scheme 1). A number of rarely used acylating agents were employed for this purpose (Scheme 2 and Table 1) and the physicochemical properties of the synthesized compounds were presented in the (Table 2). The structure of the acylated products were ascertained by analyzing their FTIR and ${ }^{1} \mathrm{H}-\mathrm{NMR}$ spectra [29]-[31]. In continuation of a project going on the carbohydrate and protein chemistry laboratory, we intended to prepare a series of uridine derivatives for use as test compounds for biological evaluation. Keeping this objective in mind, we thus prepared a set of derivatives containing a wide variety of substituents in a single molecular framework. The reaction pathways have been summarized in the Scheme 1 and Scheme 2 and Table 1.

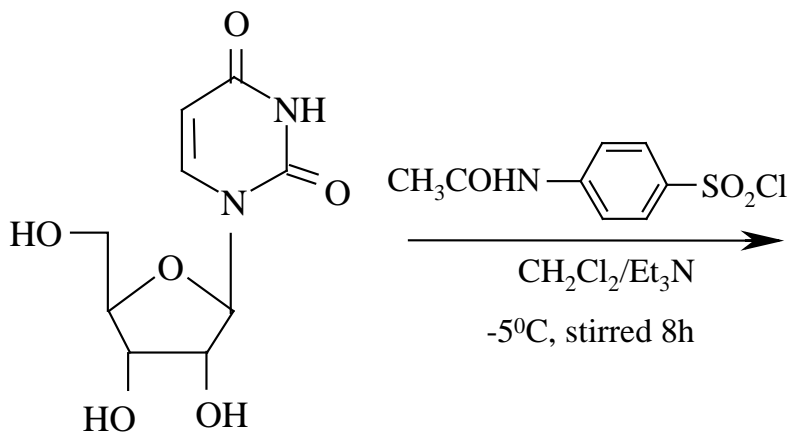

Uridine (1)<smiles>CC(=O)Nc1ccc(S(=O)(=O)OCC2OC(n3ccc(=O)[nH]c3=O)C(O)C2O)cc1</smiles>

5'-O-N-acetylsulfanilyluridine (2) (61\%)

Scheme 1. Synthesis of 5'-O-N-acetylsulfanilyluridine (2).

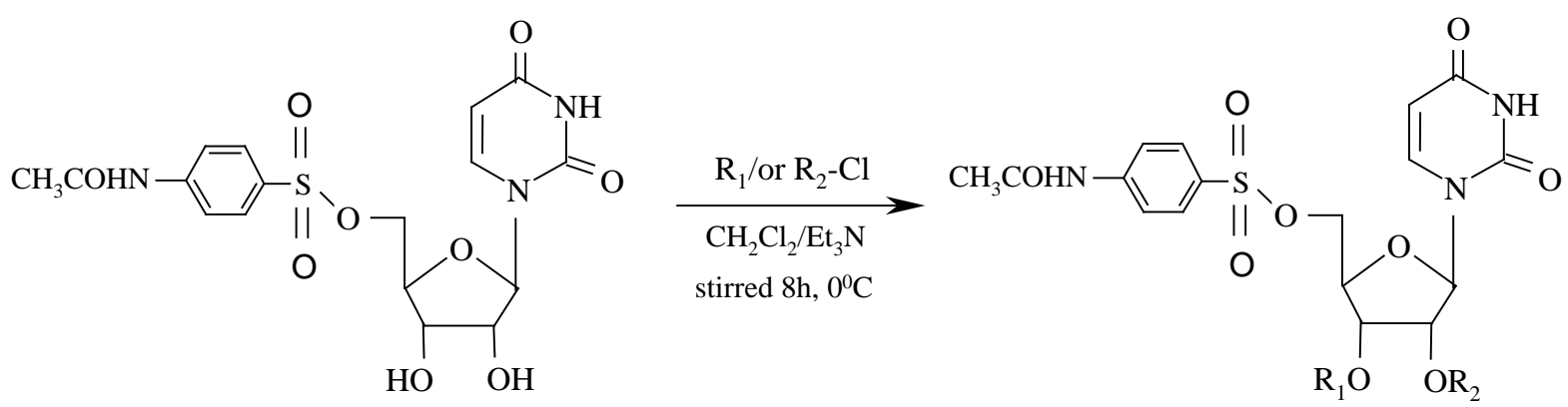


Table 1. Synthesized of uridine derivatives (2-14).

\begin{tabular}{cccc}
\hline Compound no & $\mathbf{R}_{\mathbf{1}}=\mathbf{R}_{\mathbf{2}}$ & Compound no & $\mathbf{R}_{\mathbf{1}}=\mathbf{R}_{\mathbf{2}}$ \\
\hline $\mathbf{2}$ & $\mathrm{H}$ & $\mathbf{9}$ & $\mathrm{CH}_{3}\left(\mathrm{CH}_{2}\right)_{14} \mathrm{CO}-$ \\
$\mathbf{3}$ & $\mathrm{CH}_{3} \mathrm{CO}$ & $\mathbf{1 0}$ & $\left(\mathrm{CH}_{3}\right)_{3} \mathrm{CCO}-$ \\
$\mathbf{4}$ & $\mathrm{CH}_{3}\left(\mathrm{CH}_{2}\right)_{3} \mathrm{CO}-$ & $\mathbf{1 1}$ & $\mathrm{C}_{6} \mathrm{H}_{5} \mathrm{CO}-$ \\
$\mathbf{5}$ & $\mathrm{CH}_{3}\left(\mathrm{CH}_{2}\right)_{4} \mathrm{CO}-$ & $\mathbf{1 2}$ & 3-Cl. $\mathrm{C}_{6} \mathrm{H}_{4} \mathrm{CO}-$ \\
$\mathbf{6}$ & $\mathrm{CH}_{3}\left(\mathrm{CH}_{2}\right)_{8} \mathrm{CO}-$ & $\mathbf{1 3}$ & 4-Cl. $\mathrm{C}_{6} \mathrm{H}_{4} \mathrm{CO}-$ \\
$\mathbf{8}$ & $\mathrm{CH}_{3}\left(\mathrm{CH}_{2}\right)_{10} \mathrm{CO}-$ & $\mathbf{1 4}$ & 2,6-di.Cl.C $\mathrm{C}_{6} \mathrm{CO}-$ \\
\hline
\end{tabular}

Table 2. Physicochemical properties of the synthesized of uridine derivatives (2-14).

\begin{tabular}{ccccc}
\hline Compound no & RT (h) & $\mathbf{R}_{f}$ & Yield (\%) & Physical State \\
\hline $\mathbf{2}$ & 8 & 0.5 & 61 & needles, m.p. $210^{\circ} \mathrm{C}-212^{\circ} \mathrm{C}$ \\
$\mathbf{3}$ & 7 & 0.5 & 71 & semi solid \\
$\mathbf{4}$ & 6 & 0.52 & 68 & pasty mass \\
$\mathbf{5}$ & 6 & 0.51 & 63 & thick syrup \\
$\mathbf{6}$ & 6 & 0.5 & 63 & syrup \\
$\mathbf{7}$ & 6.5 & 0.52 & 60 & needles, m.p. $74^{\circ} \mathrm{C}-75^{\circ} \mathrm{C}$ \\
$\mathbf{8}$ & 7 & 0.53 & 58 & needles, m.p. $65^{\circ} \mathrm{C}-70^{\circ} \mathrm{C}$ \\
$\mathbf{9}$ & 6 & 0.51 & 65 & needles, $\mathrm{m} \cdot \mathrm{p} \cdot 58^{\circ} \mathrm{C}-60^{\circ} \mathrm{C}$ \\
$\mathbf{1 0}$ & 6.5 & 0.5 & 70 & pasty mass \\
$\mathbf{1 1}$ & 6.5 & 0.51 & 66 & needles, m.p. $138^{\circ} \mathrm{C}-140^{\circ} \mathrm{C}$ \\
$\mathbf{1 2}$ & 6 & 0.52 & 63 & needles, m.p. $123^{\circ} \mathrm{C}-125^{\circ} \mathrm{C}$ \\
$\mathbf{1 3}$ & 6.5 & 0.5 & 60 & needles, m.p. $128^{\circ} \mathrm{C}-130^{\circ} \mathrm{C}$ \\
$\mathbf{1 4}$ & 6 & 6.52 & & thick syrupy
\end{tabular}

\subsection{Spectral Characterization}

Our initial effort was to react uridine (1) with equivalent amount of $N$-acetylsulfanilyl chloride and triethylamine in anhydrous dichloromethane at room temperature, followed by removal of solvent and silica gel column chromatographic purification, furnished the $N$-acetylsulfanilyl derivative (2). The IR spectrum of compound 2 showed absorption bands at: $1740 \mathrm{~cm}^{-1}$ (-CO stretching), $3510 \mathrm{~cm}^{-1}$ (-OH stretching), $3360 \mathrm{~cm}^{-1}$ (-NH stretching) and $1365 \mathrm{~cm}^{-1}$ (-SO $\mathrm{SO}_{2}$ stretching). In its ${ }^{1} \mathrm{H}-\mathrm{NMR}$ spectrum displayed two two-proton doublets at $\delta 7.78$ $(2 \mathrm{H}, J=8.8 \mathrm{~Hz})$ and $\delta 7.68(2 \mathrm{H}, J=8.8 \mathrm{~Hz})$ corresponding to the aromatic ring protons, one one-proton singlet at $\delta 7.53(-\mathrm{NH})$, one three-proton singlet at $\delta 2.22\left(\mathrm{CH}_{3} \mathrm{CON}-\right)$ thereby suggesting the introduction of one $N$ acetylsulfanilyl (4-acetamidobenzenesulfonyl) group in the molecule. Also, the C-5' proton was deshielded considerably to $\delta 5.77\left(1 \mathrm{H}, \mathrm{dd}, J=2.2\right.$ and $\left.12.2 \mathrm{~Hz}, 5^{\prime} \mathrm{a}\right)$ and $5.73(1 \mathrm{H}, J=2.2$ and $12.3 \mathrm{~Hz}, 5$ 'b) from its usual value, suggested the introduction of the $\mathrm{N}$-acetylsulfanilyl group at position 5 '. Complete analysis of the IR and ${ }^{1} \mathrm{H}$-NMR spectra of this compound was in agreement with the structure accorded as 5 -O $\mathrm{O}-\mathrm{N}$-acetylsulfanilyluridine (2).

The structure of compound (2) was further confirmed by preparation of its acetyl derivatives (3). Thus, acetylation of compound $\mathbf{2}$ with acetic anhydride, followed by removal of solvent and purification by silica gel column chromatography, provided the tri-O-acetyl derevative (3). Complete analysis of the rest of the IR and 
${ }^{1} \mathrm{H}$-NMR spectra was in supported the structure ascertained as 5'-O- $\mathrm{N}$-acetylsulfanilyl-2',3'-di-O-acetyluridine (3). Thus, pentanoylation of compound 2 in $\mathrm{CH}_{2} \mathrm{Cl}_{2} / \mathrm{Et}_{3} \mathrm{~N}$ using silica gel chromatographic purification afforded the pentanoyl derivative (4). In its ${ }^{1} \mathrm{H}$-NMR spectrum, the resonance peaks three four-proton multiplets at $\delta 2.42$ $\left\{2 \times \mathrm{CH}_{3}\left(\mathrm{CH}_{2}\right)_{2} \mathrm{CH}_{2} \mathrm{CO}-\right\}$ and $\delta 1.64\left\{2 \times \mathrm{CH}_{3} \mathrm{CH}_{2} \mathrm{CH}_{2} \mathrm{CH}_{2} \mathrm{CO}-\right\}$ and $\delta 1.42\left\{2 \times \mathrm{CH}_{3} \mathrm{CH}_{2}\left(\mathrm{CH}_{2}\right)_{2} \mathrm{CO}-\right\}$ and one six-proton multiplet at $\delta 0.89\left\{2 \times \mathrm{CH}_{3}\left(\mathrm{CH}_{2}\right)_{3} \mathrm{CO}\right.$ - $\}$ showed the presence of two pentanoyl groups in the molecule. Thus, complete analysis of the IR and ${ }^{1} \mathrm{H}-\mathrm{NMR}$ spectra established the structure of this compound as 5'-O- $\mathrm{N}$-acetylsulfanilyl-2',3'-di-O-pentanoyluridine (4). Reaction of compound 2 with hexanoyl chloride as usual method, provided the hexanoyl derivative (5). The ${ }^{1} \mathrm{H}-\mathrm{NMR}$ spectrum displayed characteristics two four-proton multiplets at $\delta 2.38$ and $\delta 1.63$, an eight-proton multiplet at $\delta 1.29$ and one six-proton multiplet at $\delta 0.95$ showing the attachment of two hexanoyl groups in the compound. The rest of the IR and ${ }^{1} \mathrm{H}-\mathrm{NMR}$ spectra enabled us to assign the structure of the hexanoyl derivative as 5'-O- $\mathrm{N}$-acetylsulfanilyl-2',3'-di-O-hexanoyluridine (5).

We then treated compound 2 with decanoyl chloride in anhydrous $\mathrm{CH}_{2} \mathrm{Cl}_{2} / \mathrm{Et}_{3} \mathrm{~N}$, we obtained the 2',3'-di-Odecanoyl derivative (6). Complete analysis of the IR and ${ }^{1} \mathrm{H}-\mathrm{NMR}$ spectra was consistent with the structure of the compound assigned as 5'-O- $\mathrm{N}$-acetylsulfanilyl-2',3'-di-O-decanoyluridine (6). The $\mathrm{N}$-acetylsulfanilyl derivative (2) was then subjected to lauroylation using same method and obtained in good yield as needless. It's ${ }^{1} \mathrm{H}$-NMR spectrum displayed two four-proton multiplets at 2.37, $\delta 1.64$, a thirty two-proton multiplet at $\delta 1.24$ and a nine-proton multiplet at $\delta 0.87$, therefore, indicating the presence of two lauroyl groups. So, analysis of rest of the IR and ${ }^{1} \mathrm{H}$-NMR spectra, the structure of the lauroyl derivative was assigned as 5 '-O-N-acetylsulfanilyl-2',3'-di-O-lauroyluridine (7). The diol (2) reacted with myristoyl chloride in anhydrous dichloromethane and triethylamine followed by removal of solvent and chromatographic purification, it yielded the myristate (8). As same analysis of the IR and ${ }^{1} \mathrm{H}$-NMR spectra of the compound 9 was in agreement with the structure established as 5'-O-N-acetylsulfanilyl-2',3'-di-O-palmitoyluridine (9).

Our next effort was to treat compound 2 with unimolecular amount of pivaloyl chloride in anhydrous $\mathrm{CH}_{2} \mathrm{Cl}_{2} / \mathrm{Et}_{3} \mathrm{~N}$ by silica gel chromatography furnished the pivaloyl derivative (10). The downfield shift of H-2' proton to $\delta 5.31(1 \mathrm{H}, \mathrm{m})$ and $\mathrm{H}-3^{\prime}$ proton to $\delta 5.10(1 \mathrm{H}, \mathrm{m})$ from their precursor diol (2) $\delta$ values showed the attachment of the pivaloyl groups at positions 2 ' and 3 '. The rest of the IR and ${ }^{1} \mathrm{H}-\mathrm{NMR}$ spectra was compatible with the structure assigned as 5'-O-N-acetylsulfanilyl-2',3'-di-O-pivaloyluridine (10). Benzoylation of the $\mathrm{N}$-acetylsulfanilyl derivative (2) with benzoyl chloride and further purification procedure provided the benzoyl derivative (11) in good yields. In its ${ }^{1} \mathrm{H}-\mathrm{NMR}$ spectrum, the aromatic proton peaks at $\delta 8.10(4 \mathrm{H}, \mathrm{m}), \delta 7.66(2 \mathrm{H}$, $\mathrm{m}), \delta 7.49(4 \mathrm{H}, \mathrm{m})$ corresponded to two benzoyl groups present in the compound. Complete analysis of the IR and ${ }^{1} \mathrm{H}-\mathrm{NMR}$ spectrum suggested that the structure of this compound may be assigned as 5 '-O- $\mathrm{N}$-acetylsulfanilyl-2',3'-di-O-benzoyluridine (11).

Encouraged by the results obtained so far, we then used 3-chlorobenzoyl chloride as the next acylating agent. Treatment of compound 2 with 3-chlorobenzoyl chloride and silica gel chromatographic purification, furnished the 2',3'-substitution product (12). In its ${ }^{1} \mathrm{H}-\mathrm{NMR}$ spectrum, the peaks at $\delta 7.92(2 \mathrm{H}, J=7.5 \mathrm{~Hz}), \delta 7.90(2 \mathrm{H}, \mathrm{s})$, $\delta 7.79(2 \mathrm{H}, J=7.7 \mathrm{~Hz})$ and $\delta 7.48(2 \mathrm{H}, J=7.6 \mathrm{~Hz})$ corresponded to eight aromatic protons and were due to the presence of two 3-chlorobenzoyl groups. By complete analysis of the IR and ${ }^{1} \mathrm{H}$-NMR spectra, the structure of the compound was ascertained as 5'-O- $N$-acetylsulfanilyl-2',3'-di-O-(3-chlorobenzoyl)uridine (12). After similar solvent removal and chromatographic techniques, the 4-chlorobenzoyl derivative (13) was isolated in good yield. In its ${ }^{1} \mathrm{H}-\mathrm{NMR}$ spectrum showed the deshielding of H-2' and H-3' protons from their precursor compound (2) and the resonance of other protons in their anticipated positions confirmed the structure of this compound as 5'-O- $\mathrm{N}$-acetylsulfanilyl-2',3'-di-O-(4-chlorobenzoyl)uridine (13).

Final confirmation of the structure of the compound 2 was provided by preparation of its 2,6-di-O-benzoyl derivative (14). The ${ }^{1} \mathrm{H}-\mathrm{NMR}$ spectrum displayed a six proton multiplet at $\delta 7.46$ (6H, Ar-H) corresponded to two 2,6-dichlorobenzoyl groups present in the compound. The H-2' and H-3' protons resonated at $\delta 5.49(1 \mathrm{H}, J$ $=5.1 \mathrm{~Hz})$ and $\delta 5.35(1 \mathrm{H}, \mathrm{m})$ shifted downfield from their precursor compound (2), which were indicative of the attachment of the 2,6-dochlorobenzoyl groups at 2' and 3' positions. Complete analysis of the IR and ${ }^{1} \mathrm{H}-\mathrm{NMR}$ spectrum was in accord with the structure of this compound assigned as 5'-O- $\mathrm{N}$-acetylsulfanilyl-2',3'-di-O(2,6-dichlorobenzoyl)uridine (14).

Thus, selective acylation of uridine (1) with a number of acylating agents by using the direct method was carried out successfully. The study was found to be very promising since in all the cases, a single monosubstitution product was isolated reasonably high yields. Furthermore, the $N$-acetylsulfanilyl acylation product was converted into a series of acyl derivatives (3-14). These newly synthesized products may be used as important pre- 
cursors for the modification of the uridine molecule at different positions. All the acylation products of uridine (1) and their derivatives have been employed for determining their antibacterial activity against a number of human pathogens and cytotoxicity activity by brine shrimp lethality bioassay.

\subsection{Antibacterial Activities}

The antibacterial screening results in (Table 3) and (Figure 2) showed that, in case of Gram-positive organism, 5'-O-N-acetylsulfanilyl-2',3'-di-O-lauroyluridine (7) exhibited the highest activity (14.0 mm), whereas 5'-O- $\mathrm{N}$ -

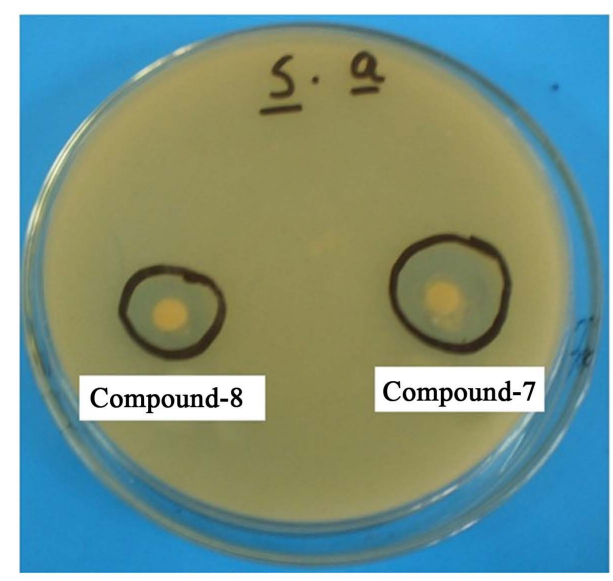

(a)

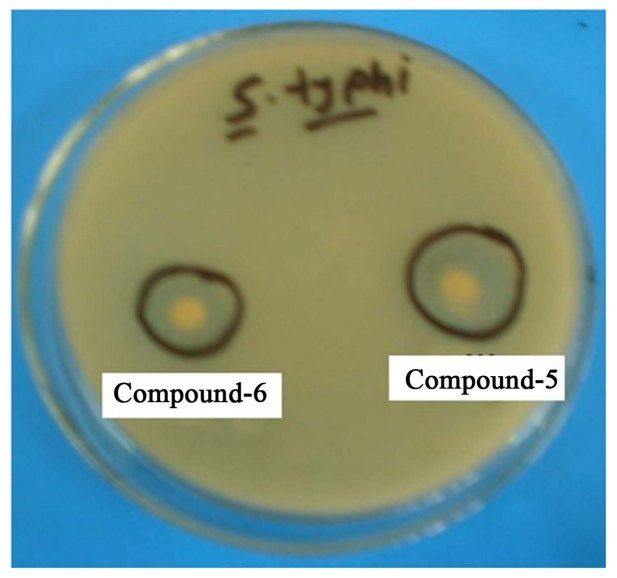

(b)

Figure 2. (a) Growth of inhibition zone observed against Gram-positive S. aureus by two test chemicals 7 and 8 and (b) against Gram-negative $S$. typhi by test chemicals $\mathbf{5}$ and $\mathbf{6}$.

Table 3. Antibacterial activity of synthesized uridine derivatives with standard antibiotic.

\begin{tabular}{|c|c|c|c|c|c|c|}
\hline \multirow{3}{*}{ Compound No. } & \multicolumn{6}{|c|}{ Zone of inhibition (mm) at $200 \mu \mathrm{g} \mathrm{dw} /$ disc } \\
\hline & \multicolumn{3}{|c|}{ Gram + Ve bacteria } & \multicolumn{3}{|c|}{ Gram - Ve bacteria } \\
\hline & B. cereus & B. megaterium & S. aureus & E. coli & S. typhi & S. paratyphi \\
\hline 2 & $\mathrm{NF}$ & $\mathrm{NF}$ & $\mathrm{NF}$ & $\mathrm{NF}$ & $\mathrm{NF}$ & $\mathrm{NF}$ \\
\hline 3 & $\mathrm{NF}$ & $\mathrm{NF}$ & NF & NF & NF & NF \\
\hline 4 & 5.4 & $\mathrm{NF}$ & 7 & $\mathrm{NF}$ & 8 & 7 \\
\hline 5 & 4.5 & 6 & 6 & $* 10$ & *13 & *12 \\
\hline 6 & $\mathrm{NF}$ & 5 & 6 & $\mathrm{NF}$ & *10 & 9 \\
\hline 7 & $\mathrm{NF}$ & $\mathrm{NF}$ & *14 & $\mathrm{NF}$ & $\mathrm{NF}$ & $\mathrm{NF}$ \\
\hline 8 & *10 & 5.5 & ${ }^{*} 12$ & 8 & 6 & 7 \\
\hline 9 & $\mathrm{NF}$ & *11 & 5 & 6 & $\mathrm{NF}$ & 8 \\
\hline 10 & ${ }^{*} 12$ & $* 10$ & 4 & $\mathrm{NF}$ & 5.5 & $\mathrm{NF}$ \\
\hline 11 & $\mathrm{NF}$ & $\mathrm{NF}$ & NF & $\mathrm{NF}$ & $\mathrm{NF}$ & $\mathrm{NF}$ \\
\hline 12 & 8 & $\mathrm{NF}$ & $\mathrm{NF}$ & $\mathrm{NF}$ & 4 & 5 \\
\hline 13 & $\mathrm{NF}$ & $\mathrm{NF}$ & $\mathrm{NF}$ & $\mathrm{NF}$ & $\mathrm{NF}$ & $\mathrm{NF}$ \\
\hline 14 & 7 & $\mathrm{NF}$ & $\mathrm{NF}$ & $\mathrm{NF}$ & $\mathrm{NF}$ & $\mathrm{NF}$ \\
\hline${ }^{* *}$ Ampicillin & ${ }^{*} 14$ & ${ }^{*} 12$ & *19 & ${ }^{*} 16$ & ${ }^{*} 20$ & $* 18$ \\
\hline
\end{tabular}

N.B: ${ }^{*}=$ marked inhibition, ${ }^{* *}=$ standard antibiotic, $\mathrm{NF}=$ not found, $\mathrm{dw}=$ dry weight. 
acetylsulfanilyl-2',3'-di-O-pivaloyluridine (10) showed lowest inhibition $(4.0 \mathrm{~mm})$ against the same organism, Staphylococcus aureus. The inhibition by compound 8 in case of Bacillus cereus (10.0 mm), Staphylococcus aureus $(12.0 \mathrm{~mm})$, by $\mathbf{9}$ in case of Bacillus magaterium (11.0 mm), and by $\mathbf{1 0}$ in case of Bacillus cereus (12.0 $\mathrm{mm})$, Bacillus magaterium $(10.0 \mathrm{~mm}$ ) were very significant. But compound 2, 3, 11 and $\mathbf{1 3}$ were unable to show any inhibition against all tested Gram-positive microorganisms. The results in Table 2 revealed that that the test chemical 5 was highly active towards the growth of all the Gram-negative bacteria. The inhibitions of growth of bacteria were very remarkable in many cases which was in conformity with our previous work [32]-[35]. Of the test chemicals 6, 8, 9, and 12 were very effective towards the inhibition of growth of maximum Gram-negative bacterial strains used. In general, it has been observed that antibacterial results of the selectively acylated uridine derivatives obtained by using various acylating agents follow the order for Gram-positive organisms: $7>10>$ $\mathbf{9}>\mathbf{8}>\mathbf{4}>5$ and Gram-negative bacteria follow the order: $5>6>8>9>10>12$.

From the results we observed that the introduction of some specific functionalities in the test chemicals improved their antibacterial activities. In this series the presence of hexanoyl, lauroyl, myristoyl, palmitoyl, pivaloyl and 3-chlorobenzoyl groups might be responsible for the enhancement of the antibacterial capacity of the test chemicals. The results reported in Table 3 revealed that the hydrophobicity is the primary contributor to antibacterial activity. Here the hydrophobicity of the molecules increased gradually from compound 4 to 9 . The hydrophobicity of materials is an important parameter with respect to such bioactivity as toxicity or alteration of membrane integrity, because it is directly related to membrane permeation [36]. Hunt [37] also proposed that the potency of aliphatic alcohols is directly related to their lipid solubility through the hydrophobic interaction between alkyl chains from alcohols and lipid regions in the membrane. We believe that a similar hydrophobic interaction might occur between the acyl chains of uridine accumulated in the lipid like nature of the bacteria membranes. As a consequence of their hydrophobic interaction, bacteria lose their membrane permeability, ultimately causing death of the bacteria [36]-[38].

\subsection{Cytotoxicity Test by Brine Shrimp Lethality Assay}

The brine shrimp lethality assay is considered a useful tool for assessment of toxicity. It is based on the ability to kill laboratory-cultured Artemia nauplii brine shrimp. The assay is considered a useful tool for preliminary assessment of toxicity and it has been used for the detection of fungal toxins, plant extract toxicity, cyanobacteria toxins and cytotoxicity testing of dental materials. The cytotoxic activity of the acylated derivatives of uridine (Scheme 1 and Scheme 2) in the brine shrimp lethality bioassay is presented in (Figure 3) and shows the percentage of mortality of shrimps at 24 hrs. The number of survived nauplii in each vial was counted for every concentration of each compound and the results were noted. However, some compounds showed a significant

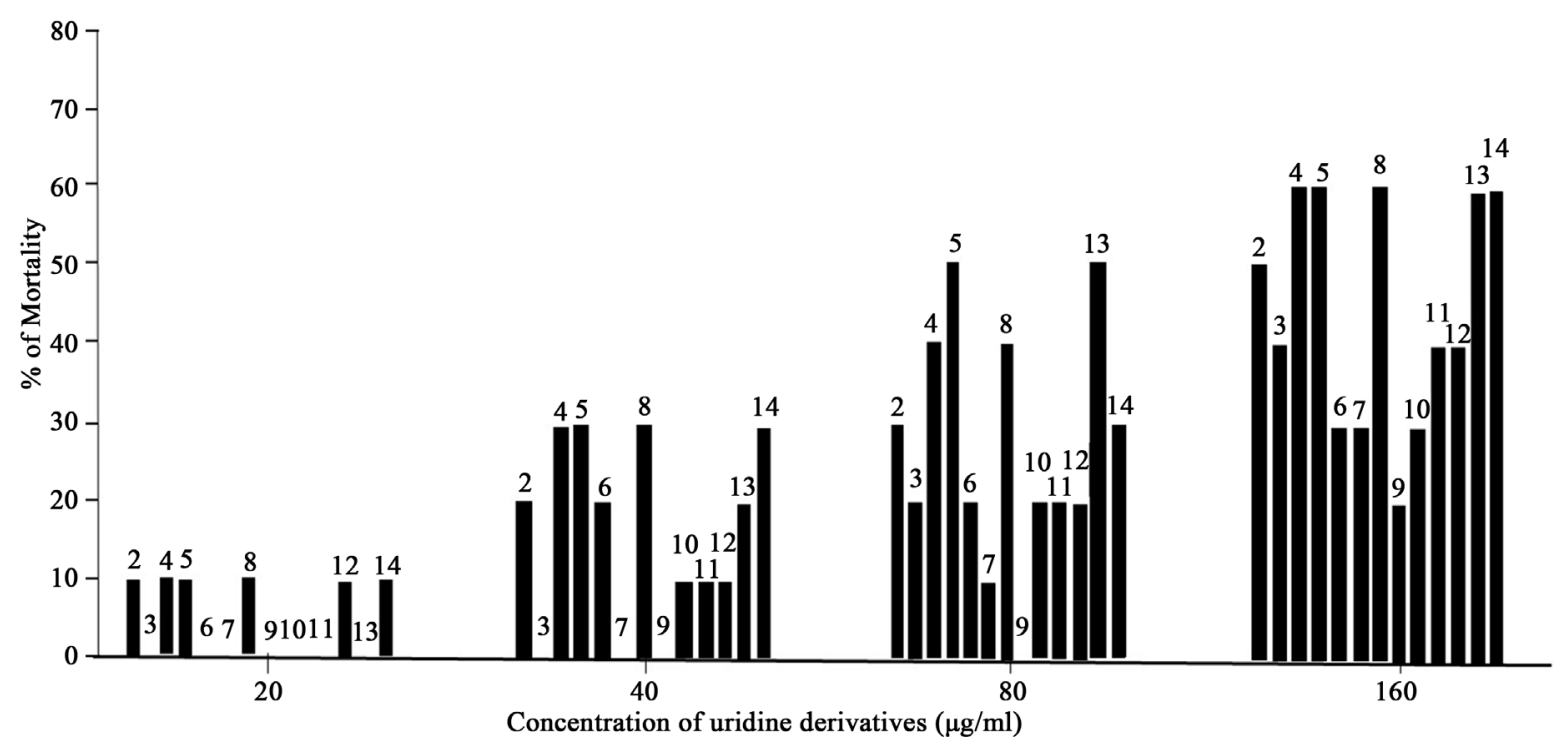

Figure 3. Graph of concentration $(\mathrm{g} / \mathrm{ml})$ versus percentage of brine shrimp mortality of the tested compounds. 
cytotoxicity activity in the brine shrimp lethality bioassay indicating that these compounds are biologically active. The compounds showed different rate mortality with different concentrations.

It is evident from the results of brine shrimp lethality testing that the test compounds 4, 5, 8, 13 and 14 showed highest levels of toxicity indicating its higher mortality. The mortality of brine shrimp was found to increase with the increase of concentrations of compounds. The 24 hours $\mathrm{LD}_{50}$ value of compound 2 showed 51.3369, and 43.9389, 62.8891, 63.0692, 50.3787, 51.3369, 43.9389, 50.1332, 51.3369, 55.7344, 54.3787, 68.7442, 69.0568 for compounds 3, 4, 5, 6, 7, 8, 9, 10, 11, 12, 13 and 14 respectively. To our knowledge, this is the first report on cytotoxic study of the newly synthesized uridine derivatives by brine shrimp lethality.

\section{Conclusion}

In the present investigation, we synthesized and characterized a novel series of uridine derivatives and their antibacterial \& cytotoxic activities assayed successfully. Simplicity and feasible reaction condition, good yield and safety are the key characteristics of this procedure. From the antibacterial results, we observed that compound 8, 9 and 10 were very sensitive towards all of both Gram-positive and Gram-negative bacterial organisms. Antibacterial activity of the new synthesized compounds bearing benzene and various acyl moieties revealed that some tested compounds showed good to moderate activities against selected human pathogenic strains. It has been suggested that the presence of some particular functional groups/atoms in the test compounds enhanced their sensitivities towards the growth of bacteria and also cytotoxic activities.

\section{Experimental}

\subsection{General}

All reagents used were commercially available (Sigma-Aldrich) and were used as received, unless otherwise specified. FTIR spectra were recorded by $\mathrm{CHCl}_{3}$ techniques at the Chemistry Department, University of Chittagong, Bangladesh, with an IR Affinity Fourier Transform Infrared Spectrophotometer (SHIMADZU). ${ }^{1} \mathrm{H}-$ NMR (400 MHz) spectra were recorded for solutions in $\mathrm{CDCl}_{3}$ using TMS as internal standard with a Bruker DPX-400 spectrometer at the Bangladesh Council of Scientific and Industrial Research (BCSIR) Laboratories, Dhaka, Bangladesh. Evaporations were carried out under reduced pressure using VV-1 type vacuum rotary evaporator (Germany) with a bath temperature below $40^{\circ} \mathrm{C}$. Melting points were determined on an electrothermal melting point apparatus (England) and are uncorrected. Column chromatography was performed with silica gel $\mathrm{G}_{60}$. Thin layer chromatography (t.l.c) was performed on Kieselgel $\mathrm{GF}_{254}$ and spots were detected by spraying the plates with $1 \% \mathrm{H}_{2} \mathrm{SO}_{4}$ and heating at $150^{\circ} \mathrm{C}-200^{\circ} \mathrm{C}$ until coloration took place.

\subsection{Synthesis}

\subsubsection{Synthesis of 5'-O-N-Acetylsulfanilyluridine Derivative (2)}

A suspension of uridine (1) (500 mg, $2.048 \mathrm{mmol}$ ) mixed with anhydrous dichloromethane (3 ml) and triethylamine $(0.15 \mathrm{ml})$ which was treated with $N$-acetyl sulfanilyl chloride $(0.703 \mathrm{mg})$. The reaction mixture was stirred at room temperature for $8 \mathrm{hrs}$. The progress of the reaction was monitored by T.l.c (methanol-chloroform, 1:12) which showed complete conversion of the starting material into faster moving product. Purification by passage through a silica gel column chromatography with methanol-chloroform (1:12) furnished the titled compound (2) as a white crystalline solid. Recrystallization from chloroform-hexane gave the $5^{\prime}-\mathrm{O}-\mathrm{N}$-acetylsulfanilyluridine (2).

\subsubsection{5'-O-N-Acetylsulfanilyluridine (2)}

FTIR $\left(v / \mathrm{cm}^{-1}\right): 1740(\mathrm{C}=\mathrm{O}), 3510(-\mathrm{OH}), 3360(-\mathrm{NH}), 1365\left(-\mathrm{SO}_{2}\right) .{ }^{1} \mathrm{H}-\mathrm{NMR}\left(\mathrm{CDCl}_{3}\right) \delta: 9.10(1 \mathrm{H}, \mathrm{s},-\mathrm{NH}), 7.78$ (2H, d, $J=8.8 \mathrm{~Hz}, \mathrm{Ar}-\mathrm{H}), 7.76$ (1H, d, $J=7.8 \mathrm{~Hz}, \mathrm{H}-6), 7.68$ (2H, d, $J=8.8 \mathrm{~Hz}, \mathrm{Ar}-\mathrm{H}), 7.53(1 \mathrm{H}, \mathrm{s},-\mathrm{NH}), 5.89$ $\left(1 \mathrm{H}, \mathrm{d}, J=5.5 \mathrm{~Hz}, \mathrm{H}-1^{\prime}\right), 5.81\left(1 \mathrm{H}, \mathrm{s}, 2^{\prime}-\mathrm{OH}\right), 5.77(1 \mathrm{H}, \mathrm{dd}, J=2.2$ and $12.2 \mathrm{~Hz}, \mathrm{H}-5 \mathrm{\prime a}), 5.73(1 \mathrm{H}, \mathrm{dd}, J=2.2$ and $12.3 \mathrm{~Hz}, \mathrm{H}-5$ 'b), 5.66 (1H, d, $J=8.1 \mathrm{~Hz}, \mathrm{H}-5), 5.42\left(1 \mathrm{H}, \mathrm{s}, 3^{\prime}-\mathrm{OH}\right), 4.42\left(1 \mathrm{H}, \mathrm{dd}, J=2.2\right.$ and $\left.5.4 \mathrm{~Hz}, \mathrm{H}-4^{\prime}\right)$, $4.20\left(1 \mathrm{H}, \mathrm{d}, J=5.6 \mathrm{~Hz}, \mathrm{H}-2^{\prime}\right), 4.13\left(1 \mathrm{H}, \mathrm{dd}, J=7.4\right.$ and $\left.5.4 \mathrm{~Hz}, \mathrm{H}-3^{\prime}\right), 2.22$ (3H, s, $\left.\mathrm{CH}_{3} \mathrm{CON}-\right)$. Anal. Calcd: C, 46.26; $\mathrm{H}, 4.31 \%$ for $\mathrm{C}_{17} \mathrm{H}_{19} \mathrm{O}_{9} \mathrm{~N}_{3} \mathrm{~S}$ (425). Found: C, 46.36; H, 4.35\%.

\subsubsection{General Procedure for the Synthesis of 5'-O-N-Acetylsulfanilyluridine Derivatives (3 - 14)}

A stirred and cooled $\left(\mathrm{O}^{\circ} \mathrm{C}\right)$ solution of the $5^{\prime}-\mathrm{O}-\mathrm{N}$-acetylsulfanilyluridine $(2)(100 \mathrm{mg}, 0.226 \mathrm{mmol})$ in anhydr- 
ous dichloromethane $(3 \mathrm{ml})$ and triethylamine $(0.15 \mathrm{ml})$ were separately treated with acetic anhydride $\left(\mathrm{Ac}_{2} \mathrm{O}\right)$ $(0.084 \mathrm{ml})$, pentanoyl chloride $(0.13 \mathrm{ml})$, hexanoyl chloride $(0.15 \mathrm{ml})$, decanoyl chloride $(0.23 \mathrm{ml})$, lauroyl chloride $(0.25 \mathrm{ml})$, myristoyl chloride $(0.31 \mathrm{ml})$, palmitoyl chloride $(0.34 \mathrm{ml})$, pivaloyl chloride $(0.14 \mathrm{ml})$, benzoyl chloride $(0.08 \mathrm{ml})$, 3-chlorobenzoyl chloride $(0.13 \mathrm{ml})$, 4-chlorobenzoyl chloride $(0.15 \mathrm{ml})$, and 2,6-di-chlorobenzoyl chloride $(0.14 \mathrm{ml})$ respectively. The reaction mixture was stirred at room temperature for 8 hrs. The progress of the reaction was monitored by T.l.c (methanol-chloroform, 1:16) which showed complete conversion of the starting material into faster moving product $\left(R_{f}=0.50\right)$. Excess reagent was destroyed by the addition of a few pieces of ice and the reaction mixture was extracted with chloroform $\left(\mathrm{CHCl}_{3}\right)(3 \times 10 \mathrm{ml})$. The combined organic extract was washed successively with dilute hydrochloric acid $(\mathrm{HCl})$, saturated aqueous sodium hydrogen carbonate $\left(\mathrm{NaHCO}_{3}\right)$ solution and water $\left(\mathrm{H}_{2} \mathrm{O}\right)$. The organic layer was dried magnesium sulfate $\left(\mathrm{MgSO}_{4}\right)$, filtered, and the filtrate was evaporated off. The resulting syrupy residue was passed through silica gel column chromatography and eluted with methanol-chloroform (1:16) to afford compounds 2',3'-di-O-acetyl derivative $3,4,5,6,7,8,9,10,11,12,13$ and 14 , respectively.

\subsubsection{5'-O-N-Acetylsulfanilyl-2,3'-di-O-Acetyluridine (3)}

FTIR $\left(v / \mathrm{cm}^{-1}\right): 1768,1760,1684(\mathrm{C}=\mathrm{O}), 3322(-\mathrm{NH}), 1362\left(-\mathrm{SO}_{2}\right) .{ }^{1} \mathrm{H}-\mathrm{NMR}\left(\mathrm{CDCl}_{3}\right) \delta: 9.08(1 \mathrm{H}, \mathrm{s},-\mathrm{NH})$, 7.70 (2H, d, $J=8.7 \mathrm{~Hz}, \mathrm{Ar}-\mathrm{H}), 7.68(1 \mathrm{H}, \mathrm{d}, J=7.8 \mathrm{~Hz}, \mathrm{H}-6), 7.62(2 \mathrm{H}, \mathrm{d}, J=8.8 \mathrm{~Hz}, \mathrm{Ar}-\mathrm{H}), 7.51(1 \mathrm{H}, \mathrm{s},-\mathrm{NH})$, $5.79\left(1 \mathrm{H}, \mathrm{d}, J=5.5 \mathrm{~Hz}, \mathrm{H}-1^{\prime}\right), 5.69\left(1 \mathrm{H}, \mathrm{dd}, J=2.2\right.$ and $\left.12.2 \mathrm{~Hz}, \mathrm{H}-5^{\prime} \mathrm{a}\right), 5.65\left(1 \mathrm{H}, \mathrm{d}, J=2.1\right.$ and $\left.12.3 \mathrm{~Hz}, \mathrm{H}-5^{\prime} \mathrm{b}\right)$, $5.61(1 \mathrm{H}, \mathrm{d}, J=8.0 \mathrm{~Hz}, \mathrm{H}-5), 5.13\left(1 \mathrm{H}, \mathrm{d}, J=5.5 \mathrm{~Hz}, \mathrm{H}-2{ }^{\prime}\right), 5.05(1 \mathrm{H}, \mathrm{dd}, J=7.3$ and $5.2 \mathrm{~Hz}, \mathrm{H}-3$ '), $4.44(1 \mathrm{H}$, m, $\mathrm{H}-4$ '), 2.22 (3H, s, $\left.\mathrm{CH}_{3} \mathrm{CON}-\right)$, 2.11, 2.03 ( $2 \times 3 \mathrm{H}, 2 \times$ s, $\left.2 \times \mathrm{CH}_{3} \mathrm{CO}-\right)$. Anal. Calcd: C, 48.0; H, 4.38\% for $\mathrm{C}_{21} \mathrm{H}_{23} \mathrm{O}_{11} \mathrm{~N}_{3} \mathrm{~S}$ (509). Found: C, 48.06; H, 4.42\%.

\subsubsection{5'-O-N-Acetylsulfanilyl-2',3'-di-O-Pentanoyluridine (4)}

FTIR $\left(v / \mathrm{cm}^{-1}\right): 1738(\mathrm{C}=\mathrm{O}), 3360(-\mathrm{NH}), 1358\left(-\mathrm{SO}_{2}\right) .{ }^{1} \mathrm{H}-\mathrm{NMR}\left(\mathrm{CDCl}_{3}\right) \delta: 8.49(1 \mathrm{H}, \mathrm{s},-\mathrm{NH}), 7.92(2 \mathrm{H}, \mathrm{d}, J=$ $8.7 \mathrm{~Hz}, \mathrm{Ar}-\mathrm{H}), 7.49$ (1H, d, $J=7.9 \mathrm{~Hz}, \mathrm{H}-6), 7.47(2 \mathrm{H}, \mathrm{d}, J=8.7 \mathrm{~Hz}, \mathrm{Ar}-\mathrm{H}), 7.35(1 \mathrm{H}, \mathrm{s},-\mathrm{NH}), 6.18(1 \mathrm{H}, \mathrm{d}, J=$ $\left.5.6 \mathrm{~Hz}, \mathrm{H}-1^{\prime}\right), 5.72(1 \mathrm{H}, \mathrm{dd}, J=2.2$ and $12.2 \mathrm{~Hz}, \mathrm{H}-5 \mathrm{\prime}$ ) $), 5.63(1 \mathrm{H}, \mathrm{dd}, J=2.1$ and $12.2 \mathrm{~Hz}, \mathrm{H}-5$ 'b), $5.48(1 \mathrm{H}, \mathrm{d}, J$ $=7.8 \mathrm{~Hz}, \mathrm{H}-5), 4.52\left(1 \mathrm{H}, \mathrm{d}, J=5.2 \mathrm{~Hz}, \mathrm{H}-2^{\prime}\right), 4.48\left(1 \mathrm{H}, \mathrm{dd}, J=7.7\right.$ and $\left.5.6 \mathrm{~Hz} \mathrm{H}-3^{\prime}\right), 4.43\left(1 \mathrm{H}, \mathrm{m}, \mathrm{H}-4^{\prime}\right), 2.42$ $\left\{4 \mathrm{H}, \mathrm{m}, 2 \times \mathrm{CH}_{3}\left(\mathrm{CH}_{2}\right)_{2} \mathrm{CH}_{2} \mathrm{CO}-\right\}, 2.26\left(3 \mathrm{H}, \mathrm{s}, \mathrm{CH}_{3} \mathrm{CON}-\right), 1.64\left(4 \mathrm{H}, \mathrm{m}, 2 \times \mathrm{CH}_{3} \mathrm{CH}_{2} \mathrm{CH}_{2} \mathrm{CH}_{2} \mathrm{CO}-\right), 1.42\{4 \mathrm{H}, \mathrm{m}$, $\left.2 \times \mathrm{CH}_{3} \mathrm{CH}_{2}\left(\mathrm{CH}_{2}\right)_{2} \mathrm{CO}-\right\}, 0.88\left\{6 \mathrm{H}, \mathrm{m}, 2 \times \mathrm{CH}_{3}\left(\mathrm{CH}_{2}\right)_{3} \mathrm{CO}-\right\}$. Anal. Calcd: C, 53.20; H, 5.75\% for $\mathrm{C}_{27} \mathrm{H}_{35} \mathrm{O}_{11} \mathrm{~N}_{3} \mathrm{~S}$ (593). Found: C, 53.26; H, 5.77\%.

\subsubsection{5'-O- $\mathrm{N}$-Acetylsulfanilyl-2',3'-di- $\mathrm{O}$-Hexanoyluridine (5)}

FTIR $\left(v / \mathrm{cm}^{-1}\right)$ : 1778, $1710(\mathrm{C}=\mathrm{O}), 3320(-\mathrm{NH}), 1365\left(-\mathrm{SO}_{2}\right) .{ }^{1} \mathrm{H}-\mathrm{NMR}\left(\mathrm{CDCl}_{3}\right) \delta: 8.88(1 \mathrm{H}, \mathrm{s},-\mathrm{NH}), 7.97(2 \mathrm{H}, \mathrm{d}$, $J=8.8 \mathrm{~Hz}, \mathrm{Ar}-\mathrm{H}), 7.50(1 \mathrm{H}, \mathrm{d}, J=7.8 \mathrm{~Hz}, \mathrm{H}-6), 7.48(2 \mathrm{H}, \mathrm{d}, J=8.8 \mathrm{~Hz}, \mathrm{Ar}-\mathrm{H}), 7.36(1 \mathrm{H}, \mathrm{s},-\mathrm{NH}), 6.16(1 \mathrm{H}, \mathrm{d}, J=$ $\left.5.7 \mathrm{~Hz}, \mathrm{H}-1^{\prime}\right), 5.70$ (1H, dd, $J=2.2$ and $12.2 \mathrm{~Hz}, \mathrm{H}-5 \mathrm{a}$ ), $5.66(1 \mathrm{H}, \mathrm{dd}, J=2.1$ and $12.0 \mathrm{~Hz}, \mathrm{H}-5$ 'b), 5.49 ( $1 \mathrm{H}, \mathrm{d}, J=$ $7.8 \mathrm{~Hz}, \mathrm{H}-5), 4.53(1 \mathrm{H}, \mathrm{d}, J=5.2 \mathrm{~Hz}, \mathrm{H}-2$ '), $4.49(1 \mathrm{H}, \mathrm{dd}, J=7.8$ and $5.6 \mathrm{~Hz} \mathrm{H}-3$ '), $4.46(1 \mathrm{H}, \mathrm{m}, \mathrm{H}-4$ '), $2.38\{4 \mathrm{H}$, m, $\left.2 \times \mathrm{CH}_{3}\left(\mathrm{CH}_{2}\right)_{3} \mathrm{CH}_{2} \mathrm{CO}-\right\}$, $2.31\left(3 \mathrm{H}, \mathrm{s}, \mathrm{CH}_{3} \mathrm{CON}-\right), 1.63\left\{4 \mathrm{H}, \mathrm{m}, 2 \times \mathrm{CH}_{3}\left(\mathrm{CH}_{2}\right)_{2} \mathrm{CH}_{2} \mathrm{CH}_{2} \mathrm{CO}-\right\}, 1.29\{8 \mathrm{H}, \mathrm{m}, 2 \times$ $\left.\mathrm{CH}_{3}\left(\mathrm{CH}_{2}\right)_{2} \mathrm{CH}_{2} \mathrm{CH}_{2} \mathrm{CO}-\right\}, 0.95$ \{6H, m, $\left.2 \times \mathrm{CH}_{3}\left(\mathrm{CH}_{2}\right)_{4} \mathrm{CO}-\right\}$. Anal. Calcd: C, 54.63; H, 6.12\% for $\mathrm{C}_{29} \mathrm{H}_{39} \mathrm{O}_{11} \mathrm{~N}_{3} \mathrm{~S}$ (621). Found: C, 54.66; H, 6.17\%.

\subsubsection{5'-O-N-Acetylsulfanilyl-2', 3'-di- $\mathrm{O}$-Decanoyluridine (6)}

FTIR $\left(v / \mathrm{cm}^{-1}\right)$ : 1720, $1685(\mathrm{C}=\mathrm{O}), 3368(-\mathrm{NH}), 1351\left(-\mathrm{SO}_{2}\right) .{ }^{1} \mathrm{H}-\mathrm{NMR}\left(\mathrm{CDCl}_{3}\right) \delta: 8.98(2 \mathrm{H}, \mathrm{s},-\mathrm{NH}), 7.76$ (2H, d, $J=8.7 \mathrm{~Hz}, \mathrm{Ar}-\mathrm{H}), 7.73(1 \mathrm{H}, \mathrm{d}, J=7.7 \mathrm{~Hz}, \mathrm{H}-6), 7.64(2 \mathrm{H}, \mathrm{d}, J=8.8 \mathrm{~Hz}, \mathrm{Ar}-\mathrm{H}), 7.54(1 \mathrm{H}, \mathrm{s},-\mathrm{NH}), 5.79$ (1H, m, H-1'), 5.68 (2H, m, H-5a' and H-5'b), 5.61 ( 1H, d, $J=8.2 \mathrm{~Hz}, \mathrm{H}-5), 5.10(1 \mathrm{H}, \mathrm{m}, \mathrm{H}-2$ '), 4.93 (1H, m, H-3'), $4.63\left(1 \mathrm{H}, \mathrm{m}, \mathrm{H}-4^{\prime}\right), 2.34\left\{4 \mathrm{H}, \mathrm{m}, 2 \times \mathrm{CH}_{3}\left(\mathrm{CH}_{2}\right)_{7} \mathrm{CH}_{2} \mathrm{CO}-\right\}, 2.20$ (3H, s, $\left.\mathrm{CH}_{3} \mathrm{CON}-\right), 1.64\{4 \mathrm{H}, \mathrm{m}, 2 \times$ $\left.\mathrm{CH}_{3}\left(\mathrm{CH}_{2}\right)_{6} \mathrm{CH}_{2} \mathrm{CH}_{2} \mathrm{CO}-\right\}, 1.25\left\{24 \mathrm{H}, \mathrm{m}, 2 \times \mathrm{CH}_{3}\left(\mathrm{CH}_{2}\right)_{6} \mathrm{CH}_{2} \mathrm{CH}_{2} \mathrm{CO}-\right\}, 0.89\left\{6 \mathrm{H}, \mathrm{m}, 2 \times \mathrm{CH}_{3}\left(\mathrm{CH}_{2}\right)_{8} \mathrm{CO}-\right\}$. Anal. Calcd: C, 59.28; H, 7.34\% for $\mathrm{C}_{37} \mathrm{H}_{55} \mathrm{O}_{11} \mathrm{~N}_{3} \mathrm{~S}$ (733). Found: C, 59.37; H, 7.38\%.

\subsubsection{5'-O-N-Acetylsulfanilyl-2',3'-di-O-Lauroyluridine (7)}

FTIR $\left(v / \mathrm{cm}^{-1}\right)$ : $1708(\mathrm{C}=\mathrm{O}), 3355(-\mathrm{NH}), 1360\left(-\mathrm{SO}_{2}\right) .{ }^{1} \mathrm{H}-\mathrm{NMR}\left(\mathrm{CDCl}_{3}\right) \delta$ : $8.92(1 \mathrm{H}, \mathrm{s},-\mathrm{NH}), 7.78(2 \mathrm{H}, \mathrm{m}$, Ar-H), 7.71 (1H, d, $J=7.8 \mathrm{~Hz}, \mathrm{H}-6), 7.68(2 \mathrm{H}, \mathrm{m}, \mathrm{Ar}-\mathrm{H}), 7.55(1 \mathrm{H}, \mathrm{s},-\mathrm{NH}), 5.72(1 \mathrm{H}, \mathrm{m}, \mathrm{H}-1)$ ) $5.53(1 \mathrm{H}, \mathrm{m}$, H-5'a), 5.50 (1H, m, H-5'b), 5.48 (1H, d, $J=8.1 \mathrm{~Hz}, \mathrm{H}-5), 5.13$ (1H, d, $J=5.6 \mathrm{~Hz}, \mathrm{H}-2$ '), $4.95\left(1 \mathrm{H}, \mathrm{m}, \mathrm{H}-3^{\prime}\right)$, $4.72(1 \mathrm{H}, \mathrm{m}, \mathrm{H}-4), 2.37\left\{4 \mathrm{H}, \mathrm{m}, 2 \times \mathrm{CH}_{3}\left(\mathrm{CH}_{2}\right)_{9} \mathrm{CH}_{2} \mathrm{CO}-\right\}, 2.22\left(3 \mathrm{H}, \mathrm{s}, \mathrm{CH}_{3} \mathrm{CON}-\right), 1.64\{4 \mathrm{H}, \mathrm{m}, 2 \times$ 
$\left.\mathrm{CH}_{3}\left(\mathrm{CH}_{2}\right)_{8} \mathrm{CH}_{2} \mathrm{CH}_{2} \mathrm{CO}-\right\}, 1.24\left\{32 \mathrm{H}, \mathrm{m}, 2 \times \mathrm{CH}_{3}\left(\mathrm{CH}_{2}\right)_{8} \mathrm{CH}_{2} \mathrm{CH}_{2} \mathrm{CO}-\right\}, 0.87\left\{6 \mathrm{H}, \mathrm{m}, 2 \times \mathrm{CH}_{3}\left(\mathrm{CH}_{2}\right)_{10} \mathrm{CO}-\right\}$. Anal. Calcd: C, 61.11; H, 7.83\% for $\mathrm{C}_{41} \mathrm{H}_{63} \mathrm{O}_{11} \mathrm{~N}_{3} \mathrm{~S}$ (789). Found: C, 61.16; H, 7.91\%.

\subsubsection{5'-O-N-Acetylsulfanilyl-2',3'-di-O-Myristoyluridine (8)}

FTIR $\left.\left(v / \mathrm{cm}^{-1}\right): 1720 \mathrm{C}=\mathrm{O}\right), 3370(-\mathrm{NH}), 1368\left(-\mathrm{SO}_{2}\right) .{ }^{1} \mathrm{H}-\mathrm{NMR}\left(\mathrm{CDCl}_{3}\right) \delta: 8.01(2 \mathrm{H}, \mathrm{d}, J=8.7 \mathrm{~Hz}, \mathrm{Ar}-\mathrm{H})$, $7.52(1 \mathrm{H}, \mathrm{d}, J=7.8 \mathrm{~Hz}, \mathrm{H}-6), 7.47(2 \mathrm{H}, \mathrm{m}, \mathrm{Ar}-\mathrm{H}), 7.32(2 \mathrm{H}, \mathrm{s},-\mathrm{NH}), 6.18(1 \mathrm{H}, \mathrm{d}, J=5.8 \mathrm{~Hz}, \mathrm{H}-1)$ ), $6.15(1 \mathrm{H}, \mathrm{m}$, H-5'a), 5.80 (1H, m, H-5'b), 5.51 (1H, d, $J=7.7 \mathrm{~Hz}, \mathrm{H}-5), 5.48\left(1 \mathrm{H}, \mathrm{d}, J=5.3 \mathrm{~Hz}, \mathrm{H}-2^{\prime}\right), 5.38\left(1 \mathrm{H}, \mathrm{m}, \mathrm{H}-3^{\prime}\right)$, 4.47 (1H, dd, $J=2.2$ and $5.4 \mathrm{~Hz}, \mathrm{H}-4$ '), $2.34\left\{4 \mathrm{H}, \mathrm{m}, 2 \times \mathrm{CH}_{3}\left(\mathrm{CH}_{2}\right)_{11} \mathrm{CH}_{2} \mathrm{CO}-\right\}, 2.30$ (3H, s, $\left.\mathrm{CH}_{3} \mathrm{CON}-\right), 1.29$ $\left\{44 \mathrm{H}, \mathrm{m}, 2 \times \mathrm{CH}_{3}\left(\mathrm{CH}_{2}\right)_{11} \mathrm{CH}_{2} \mathrm{CO}-\right\}, 0.87\left\{6 \mathrm{H}, \mathrm{m}, 2 \times \mathrm{CH}_{3}\left(\mathrm{CH}_{2}\right)_{12} \mathrm{CO}\right\}$. Anal. Calcd: C, 62.72; H, 8.25\% for $\mathrm{C}_{45} \mathrm{H}_{71} \mathrm{O}_{11} \mathrm{~N}_{3} \mathrm{~S}$ (845). Found: C, 62.79; H, 8.29\%.

\subsubsection{5'-O-N-Acetylsulfanilyl-2',3'-di-O-Palmitoyluridine (9)}

FTIR $\left(v / \mathrm{cm}^{-1}\right)$ : 1718, $1680(\mathrm{C}=\mathrm{O}), 3366(-\mathrm{NH}), 1358\left(-\mathrm{SO}_{2}\right) .{ }^{1} \mathrm{H}-\mathrm{NMR}\left(\mathrm{CDCl}_{3}\right) \delta: 8.78(1 \mathrm{H}, \mathrm{s},-\mathrm{NH}), 7.75(2 \mathrm{H}$, d, $J=8.8 \mathrm{~Hz}, \mathrm{Ar}-\mathrm{H}), 7.68(1 \mathrm{H}, \mathrm{m}, \mathrm{H}-6), 7.61(2 \mathrm{H}, \mathrm{m}, \mathrm{Ar}-\mathrm{H}), 7.53(1 \mathrm{H}, \mathrm{s},-\mathrm{NH}), 5.73\left(1 \mathrm{H}, \mathrm{m}, \mathrm{H}-1^{\prime}\right), 5.51(2 \mathrm{H}, \mathrm{m}$, H-5'a and H-5'b), 5.47 (1H, d, $J=8.1 \mathrm{~Hz}, \mathrm{H}-5), 5.22(1 \mathrm{H}, \mathrm{d}, J=5.5 \mathrm{~Hz}, \mathrm{H}-2$ '), $5.01(1 \mathrm{H}, \mathrm{m}, \mathrm{H}-3$ '), $4.90(1 \mathrm{H}, \mathrm{m}$, $\left.\mathrm{H}-4^{\prime}\right), 2.30\left\{4 \mathrm{H}, \mathrm{m}, 2 \times \mathrm{CH}_{3}\left(\mathrm{CH}_{2}\right)_{13} \mathrm{CH}_{2} \mathrm{CO}-\right\}, 2.23\left(3 \mathrm{H}, \mathrm{s}, \mathrm{CH}_{3} \mathrm{CON}-\right), 1.22\left\{52 \mathrm{H}, \mathrm{m}, 2 \times \mathrm{CH}_{3}\left(\mathrm{CH}_{2}\right)_{13} \mathrm{CH}_{2} \mathrm{CO}-\right\}$, 0.89 \{9H, m, $3 \times \mathrm{CH}_{3}\left(\mathrm{CH}_{2}\right)_{14} \mathrm{CO}-$ \}. Anal. Calcd: C, 64.12; H, 8.62\% for $\mathrm{C}_{49} \mathrm{H}_{79} \mathrm{O}_{11} \mathrm{~N}_{3} \mathrm{~S}$ (901). Found: C, 64.19; $\mathrm{H}, 8.71 \%$.

\subsubsection{5'-O-N-Acetylsulfanilyl-2',3'-di-O-Pivaloyluridine (10)}

FTIR $\left(v / \mathrm{cm}^{-1}\right)$ : $1740(\mathrm{C}=\mathrm{O}), 3350(-\mathrm{NH}), 1366\left(-\mathrm{SO}_{2}\right) .{ }^{1} \mathrm{H}-\mathrm{NMR}\left(\mathrm{CDCl}_{3}\right) \delta$ : $9.01(1 \mathrm{H}, \mathrm{s},-\mathrm{NH}), 7.77(2 \mathrm{H}, \mathrm{d}, J=$ $8.8 \mathrm{~Hz}, \mathrm{Ar}-\mathrm{H}), 7.73(1 \mathrm{H}, \mathrm{d}, J=7.8 \mathrm{~Hz}, \mathrm{H}-6), 7.63(2 \mathrm{H}, \mathrm{d}, J=8.8 \mathrm{~Hz}, \mathrm{Ar}-\mathrm{H}), 7.54(1 \mathrm{H}, \mathrm{s},-\mathrm{NH}), 5.80(1 \mathrm{H}, \mathrm{d}, J=$ $5.4 \mathrm{~Hz}, \mathrm{H}-1$ '), 5.68 (1H, m, H-5'a), 5.59 (1H, m, H-5'b), 5.49 (1H, d, J = 8.2 Hz, H-5), 5.31 (1H, m, H-2'), 5.10 $\left(1 \mathrm{H}, \mathrm{m}, \mathrm{H}-3^{\prime}\right), 4.88\left(1 \mathrm{H}, \mathrm{m}, \mathrm{H}-4^{\prime}\right), 2.20\left(3 \mathrm{H}, \mathrm{s}, \mathrm{CH}_{3} \mathrm{CON}-\right), 1.21$ \{18H, s, $\left.2 \times\left(\mathrm{CH}_{3}\right)_{3} \mathrm{CCO}-\right\}$. Anal. Calcd: C, 53.20; H, 5.75\% for $\mathrm{C}_{27} \mathrm{H}_{35} \mathrm{O}_{11} \mathrm{~N}_{3} \mathrm{~S}$ (593). Found: C, 53.26; H, 5.81\%.

\subsubsection{5'-O-N-Acetylsulfanilyl-2',3'-di-O-Benzoyluridine (11)}

FTIR $\left(v / \mathrm{cm}^{-1}\right)$ : $1685(\mathrm{C}=\mathrm{O}), 3369(-\mathrm{NH}), 1349\left(-\mathrm{SO}_{2}\right) .{ }^{1} \mathrm{H}-\mathrm{NMR}\left(\mathrm{CDCl}_{3}\right) \delta: 8.9(1 \mathrm{H}, \mathrm{s},-\mathrm{NH}), 8.10(4 \mathrm{H}, \mathrm{m}$, Ar-H), $7.88(2 \mathrm{H}, \mathrm{d}, J=8.7 \mathrm{~Hz}, \mathrm{Ar}-\mathrm{H}), 7.71(1 \mathrm{H}, \mathrm{d}, J=7.8 \mathrm{~Hz}, \mathrm{H}-6), 7.66(2 \mathrm{H}, \mathrm{m}, \mathrm{Ar}-\mathrm{H}), 7.52(2 \mathrm{H}, \mathrm{m}, \mathrm{Ar}-\mathrm{H})$, $7.49(4 \mathrm{H}, \mathrm{m}, \mathrm{Ar}-\mathrm{H}), 7.42(1 \mathrm{H}, \mathrm{s},-\mathrm{NH}), 5.78(1 \mathrm{H}, \mathrm{d}, J=5.5 \mathrm{~Hz}, \mathrm{H}-1$ '), 5.57 (2H, m, H-5'a and H-5'b), $5.47(1 \mathrm{H}$, d, $J=7.8 \mathrm{~Hz}, \mathrm{H}-5), 5.13\left(1 \mathrm{H}, \mathrm{d}, J=5.6 \mathrm{~Hz}, \mathrm{H}-2^{\prime}\right), 4.88\left(1 \mathrm{H}, \mathrm{m}, \mathrm{H}-3^{\prime}\right), 4.56\left(1 \mathrm{H}, \mathrm{m}, \mathrm{H}-4^{\prime}\right), 2.22(3 \mathrm{H}, \mathrm{s}$, $\mathrm{CH}_{3} \mathrm{CON}$-). Anal. Calcd: C, 57.32; H, 4.16\% for $\mathrm{C}_{31} \mathrm{H}_{27} \mathrm{O}_{11} \mathrm{~N}_{3} \mathrm{~S}$ (633). Found: C, 57.37; H, 4.18\%.

\subsubsection{5'-O-N-Acetylsulfanilyl-2',3'-di-O-(3-Chlorobenzoyl)Uridine (12)}

FTIR $\left(v / \mathrm{cm}^{-1}\right): 1738(\mathrm{C}=\mathrm{O}), 3348(-\mathrm{NH}), 1360\left(-\mathrm{SO}_{2}\right) .{ }^{1} \mathrm{H}-\mathrm{NMR}\left(\mathrm{CDCl}_{3}\right) \delta: 8.10(1 \mathrm{H}, \mathrm{s},-\mathrm{NH}), 7.92(2 \mathrm{H}, \mathrm{d}, J$ $=7.7 \mathrm{~Hz}, \mathrm{Ar}-\mathrm{H}), 7.90(2 \mathrm{H}, \mathrm{s}, \mathrm{Ar}-\mathrm{H}), 7.83(1 \mathrm{H}, \mathrm{d}, J=7.6 \mathrm{~Hz}, \mathrm{H}-6), 7.79(2 \mathrm{H}, \mathrm{d}, J=7.7 \mathrm{~Hz}, \mathrm{Ar}-\mathrm{H}), 7.58(2 \mathrm{H}, \mathrm{d}, J$ $=8.8 \mathrm{~Hz}, \mathrm{Ar}-\mathrm{H}), 7.49(2 \mathrm{H}, \mathrm{d}, J=8.8 \mathrm{~Hz}, \mathrm{Ar}-\mathrm{H}), 7.48(2 \mathrm{H}, \mathrm{t}, J=7.6 \mathrm{~Hz}, \mathrm{Ar}-\mathrm{H}), 7.42(1 \mathrm{H}, \mathrm{s},-\mathrm{NH}), 6.19(1 \mathrm{H}, \mathrm{d}$, $\left.J=6.5 \mathrm{~Hz}, \mathrm{H}-1^{\prime}\right), 5.58$ (1H, m, H-5'a), $5.83\left(1 \mathrm{H}, \mathrm{m}, \mathrm{H}-5^{\prime} \mathrm{b}\right), 5.79(1 \mathrm{H}, \mathrm{d}, J=7.8 \mathrm{~Hz}, \mathrm{H}-5), 4.78$ (1H, d, $J=5.2$ $\left.\mathrm{Hz}, \mathrm{H}-2^{\prime}\right), 4.72\left(1 \mathrm{H}, \mathrm{dd}, J=7.6\right.$ and $\left.5.5 \mathrm{~Hz}, \mathrm{H}-3^{\prime}\right), 4.36\left(1 \mathrm{H}, \mathrm{m}, \mathrm{H}-4^{\prime}\right), 2.12$ (3H, s, $\left.\mathrm{CH}_{3} \mathrm{CON}-\right)$. Anal. Calcd: C, 51.81; H, 3.48\% for $\mathrm{C}_{31} \mathrm{H}_{25} \mathrm{O}_{11} \mathrm{~N}_{3} \mathrm{SCl}_{2}$ (702). Found: C, 51.88; H, 3.53\%.

\subsubsection{5'-O-N-Acetylsulfanilyl-2',3'-di-O-(4-Chlorobenzoyl)Uridine (13)}

FTIR $\left(v / \mathrm{cm}^{-1}\right): 1680(\mathrm{C}=\mathrm{O}), 3357(-\mathrm{NH}), 1362\left(-\mathrm{SO}_{2}\right) .{ }^{1} \mathrm{H}-\mathrm{NMR}\left(\mathrm{CDCl}_{3}\right) \delta: 8.87(1 \mathrm{H}, \mathrm{s},-\mathrm{NH}), 8.03(4 \mathrm{H}, \mathrm{m}$, Ar-H), 7.96 (2H, d, $J=8.8 \mathrm{~Hz}, \mathrm{Ar}-\mathrm{H}), 7.86(1 \mathrm{H}, \mathrm{d}, J=7.7 \mathrm{~Hz}, \mathrm{H}-6), 7.47$ (2H, d, $J=8.6 \mathrm{~Hz}, \mathrm{Ar}-\mathrm{H}), 7.46(4 \mathrm{H}$, m, Ar-H), $7.39(1 \mathrm{H}, \mathrm{s},-\mathrm{NH}), 6.23\left(1 \mathrm{H}, \mathrm{d}, J=5.5 \mathrm{~Hz}, \mathrm{H}-1^{\prime}\right), 5.81(1 \mathrm{H}, \mathrm{m}, \mathrm{H}-5 \mathrm{\prime}), 5.62(1 \mathrm{H}, \mathrm{dd}, J=2.1$ and 12.2 Hz, H-5'b), $5.37(1 \mathrm{H}, \mathrm{m}, \mathrm{H}-5), 4.78\left(1 \mathrm{H}, \mathrm{m}, \mathrm{H}-2^{\prime}\right), 4.72\left(1 \mathrm{H}, \mathrm{m}, \mathrm{H}-3^{\prime}\right), 4.62\left(1 \mathrm{H}, \mathrm{m}, \mathrm{H}-4^{\prime}\right), 2.17(3 \mathrm{H}, \mathrm{s}$, $\mathrm{CH}_{3} \mathrm{CON}-$ ). Anal. Calcd: C, 51.81; H, 3.48\% for $\mathrm{C}_{31} \mathrm{H}_{25} \mathrm{O}_{11} \mathrm{~N}_{3} \mathrm{SCl}_{2}$ (702). Found: C, 51.89; $\mathrm{H}, 3.55 \%$.

\subsubsection{5'-O-N-Acetylsulfanilyl-2',3'-di-O-(2,6-Dichlorobenzoyl)Uridine (14)}

FTIR $\left(v / \mathrm{cm}^{-1}\right): 1735(\mathrm{C}=\mathrm{O}), 3335(-\mathrm{NH}), 1349\left(-\mathrm{SO}_{2}\right) .{ }^{1} \mathrm{H}-\mathrm{NMR}\left(\mathrm{CDCl}_{3}\right) \delta: 8.0(2 \mathrm{H}, \mathrm{d}, J=8.8 \mathrm{~Hz}, \mathrm{Ar}-\mathrm{H}), 7.50$ $(1 \mathrm{H}, \mathrm{d}, J=7.8 \mathrm{~Hz}, \mathrm{H}-6), 7.46(6 \mathrm{H}, \mathrm{m}, \mathrm{Ar}-\mathrm{H}), 7.42(2 \mathrm{H}, \mathrm{m}, \mathrm{Ar}-\mathrm{H}), 7.33(1 \mathrm{H}, \mathrm{s},-\mathrm{NH}), 6.29(1 \mathrm{H}, \mathrm{d}, J=5.2 \mathrm{~Hz}$, H-1'), $6.13\left(1 \mathrm{H}, \mathrm{m}, \mathrm{H}-5^{\prime} \mathrm{a}\right), 5.82\left(1 \mathrm{H}, \mathrm{m}, \mathrm{H}-5^{\prime} \mathrm{b}\right), 5.53(1 \mathrm{H}, \mathrm{d}, J=7.6 \mathrm{~Hz}, \mathrm{H}-5), 5.49$ (1H, d, $\left.J=5.1 \mathrm{~Hz}, \mathrm{H}-2^{\prime}\right)$, $5.35\left(1 \mathrm{H}, \mathrm{m}, \mathrm{H}-3^{\prime}\right), 4.42\left(1 \mathrm{H}, \mathrm{m}, \mathrm{H}-4{ }^{\prime}\right), 2.12$ (3H, s, $\left.\mathrm{CH}_{3} \mathrm{CON}-\right)$. Anal. Calcd: C, 47.27; H, 2.92\% for $\mathrm{C}_{31} \mathrm{H}_{23} \mathrm{O}_{11} \mathrm{~N}_{3} \mathrm{SCl}_{4}$ (771). Found: C, 47.33; H, 2.97\%. 


\subsection{Antibacterial Screening Studies}

\subsubsection{Test Microorganisms}

Test tube cultures of bacterial pathogens were obtained from the Microbiology Laboratory, Department of Microbiology, University of Chittagong. The synthesized test compounds (Scheme 1 and Scheme 2) were subjected to antibacterial screening against three Gram-positive and three Gram-negative bacterial strains (Table 4).

Nutrient Agar (NA) media was used throughout the study (Table 5). In all cases, a $2 \%$ solution (in $\mathrm{CHCl}_{3}$ ) of the chemicals was used.

\subsubsection{Antibacterial Activity Assay}

The in vitro antibacterial spectrum of the synthesized chemicals were done by disc diffusion method [26] with little modification [27]. Sterilized paper discs of $4 \mathrm{~mm}$ in diameter and Petri dishes of $150 \mathrm{~mm}$ in diameter were used throughout the experiment. The autoclaved Mueller-Hinton agar medium, cooled to $45^{\circ} \mathrm{C}$, was poured into sterilized Petri dishes to a depth of 3 to $4 \mathrm{~mm}$ and after solidification of the agar medium the plates were transferred to an incubator at $37^{\circ} \mathrm{C}$ for 15 to 20 minutes to dry off the moisture that developed on the agar surface. The plates were inoculated with the standard bacterial suspensions (as McFarland 0.5 standard) followed by spread plate method and allowed to dry for three to five minutes. Dried and sterilized filter paper discs were treated separately with $50 \mu \mathrm{g}$ dry weight/disc from $2 \%$ solution (in $\mathrm{CHCl}_{3}$ ) of each test chemical using a micropipette, dried in air under aseptic condition and were placed at equidistance in a circle on the seeded plate. A control plate was also maintained in each case without any test chemical. These plates were kept for 4 - 6 hours at low temperature $\left(4^{\circ} \mathrm{C}-6^{\circ} \mathrm{C}\right)$ and the test chemicals diffused from disc to the surrounding medium. The plates were then incubated at $35^{\circ} \mathrm{C} \pm 2^{\circ} \mathrm{C}$ for 24 hours to allow maximum growth of the microorganisms. The antibacterial activity of the test agent was determined by measuring the mean diameter of zone of inhibitions (in millimeter). Each experiment was repeated thrice. All the results were compared with the standard antibacterial anti-

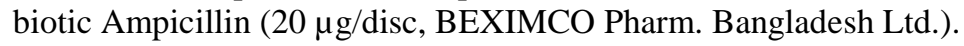

\subsection{Cytotoxic Activity by Brine Shrimp Lethality Bioassay}

Brine shrimp lethality assay of the acylated derivatives of uridine was performed according to McLaughlin et al. method [28]. The tested compounds were dissolved in DMSO and prepared 20, 40, 80 and $160 \mu$ l by adding

Table 4. List of used bacteria.

\begin{tabular}{ccc}
\hline Types of bacteria & Name of tested bacteria & Strain no. \\
\hline Gram + Ve & Bacillus cereus & BTCC 19 \\
& Bacillus megaterium & BTCC 18 \\
& Staphylococcus aureus & ATCC 6538 \\
Gram - Ve & Escherichia coli & ATCC 25922 \\
& Salmonella typhi & AE 14612 \\
\hline
\end{tabular}

Table 5. The composition of Nutrient Agar (NA) media.

\begin{tabular}{|c|c|c|}
\hline Sl no. & Name of ingredients & Amounts (g/or ml) \\
\hline 1 & Beef extract & $0.5 \mathrm{~g}$ \\
\hline 2 & Peptone & $1.0 \mathrm{~g}$ \\
\hline 3 & Agar & $1.5 \mathrm{~g}$ \\
\hline 4 & $\mathrm{NaCl}$ & $1.0 \mathrm{~g}$ \\
\hline \multirow[t]{2}{*}{5} & Distilled water & $1000 \mathrm{~mL}$ \\
\hline & Final pH 7 & \\
\hline
\end{tabular}


$\mathrm{NaCl}$ solution to each vial up to $1 \mathrm{ml}$ volume which were designated as type-A, B, C and D, respectively. Three sets of experiment were done for each concentration and 10 brine shrimps nauplii were placed in each vial. A control experiment was performed in a vial containing 10 nauplii in $1 \mathrm{ml}$ seawater. After 24 hrs of incubation at $\mathrm{RT}$, the vials were observed using a magnifying glass and the number of survivors in each vial was counted and noted. No deaths were found in the controls. From the data, the average percentage of mortality of nauplii was calculated for each concentration.

\section{Acknowledgements}

The authors are grateful to the Ministry of Education (MOE), Government of the People's Republic of Bangladesh for the financial support (Ref:: 37-01.0000.078.02.018.13-50, 2014-2015) to carrying out this research work. We are also thankful to the Chairman, Bangladesh Council of Scientific and Industrial Research (BCSIR) Laboratories, Dhaka, for providing the ${ }^{1} \mathrm{H}-\mathrm{NMR}$ spectra.

\section{References}

[1] Wen, J. and Xia, Y. (2012) Adenosine Signaling: Good or Bad in Erectile Function. Arteriosclerosis, Thrombosis, and Vascular Biology, 32, 845-850. http://dx.doi.org/10.1161/ATVBAHA.111.226803

[2] Jordheim, L.P., Durantel, D., Zoulim, F. and Dumontet, C. (2013) Advances in the Development of Nucleoside and Nucleotide Analogues for Cancer and Viral Diseases. Nature Reviews Drug Discovery, 12, 447-464. http://dx.doi.org/10.1038/nrd4010

[3] Carlezon Jr., W.A., Mague, S.D., Parow, A.M., Stoll, A.L., Cohen, B.M. and Renshaw, P.F. (2005) AntidepressantLike Effects of Uridine and Omega-3 Fatty Acids Are Potentiated by Combined Treatment in Rats. Biological Psychiatry, 57, 343-350. http://dx.doi.org/10.1016/j.biopsych.2004.11.038

[4] Jonas, D.A., Elmadfa, I., Engel, K.H., Heller, K.J., Kozianowski, G., Konig, A., Muller, D., Narbonne, J.F., Wackemagel, W. and Kleiner, J. (2001) Safety Considerations of DNA in Food. Annals of Nutrition \& Metabolism, 45, 235-254. http://dx.doi.org/10.1159/000046734

[5] WHO (2004) The Global Burden of Disease Update. World Health Organization. www.who.int/healthinfo/global burden disease/2004 report update/en/index.html

[6] Williams, J.M. and Richardson, A.C. (1967) Selective Acylation of Pyranosides-I. Benzoylation of Methyl $\alpha$-D-Glycopyranosides of Mannose, Glucose and Galactose. Tetrahedron, 23, 1369-1378. http://dx.doi.org/10.1016/0040-4020(67)85091-9

[7] Hiroyuki, H., Horoshi, A., Hiromichi, T. and Tadashi, M. (1990) Introduction of an Alkyl Group into the Sugar Portion of Uracilnucleosides by the Use of Gilman Reagents. Chemical \& Pharmaceutical Bulletin, 38, 355-360. http://dx.doi.org/10.1248/cpb.38.355

[8] Willard, J.J., Brimacombe, J.S. and Brueton, R.P. (1964) The Synthesis of 3-O-[(benzylthio)carbonyl]- $\beta$-D-Glucopyranose and Methyl 2,4,6-tri-O- $\alpha$ and $\beta$-D-Glucopyranosides. Canadian Journal of Chemistry, 42, 2560-2567. http://dx.doi.org/10.1139/v64-374

[9] Wagner, D., Verheyden, J.P.H. and Moffatt, J.G. (1974) Preparation and Synthetic Utility of Some Organotin Derivatives of Nucleosides. Journal of Organic Chemistry, 39, 24-30. http://dx.doi.org/10.1021/jo00915a005

[10] Kim, S., Chang, H. and Kim, W. (1985) Regioselective Acylation of Some Glycopyranoside Derivatives. Journal of Organic Chemistry, 50, 1751-1752. http://dx.doi.org/10.1021/jo00210a036

[11] Kabir, A.K.M.S., Dutta, P. and Anwar, M.N. (2005) Synthesis of Some New Derivatives of D-Mannose. Chittagong University Journal of Science, 29, 1-8.

[12] Ichinari, M., Nakayama, K. and Hayase, Y. (1988) Synthesis of 2,4-Dioxoimidazolidines from 2-Arylimino-1,3-thiazines and Their Antifungal Activity. Heterocycles, 27, 2635-2641. http://dx.doi.org/10.3987/COM-88-4699

[13] Gawande, N.G. and Shingare, M.S. (1987) Synthesis of Some Thiazolylthiosemicarbazides, Triazoles, Oxazoles, Thiadiazoles \& Their Microbial Activity. Indian Journal of Chemistry, 26, 387-394.

[14] Gupta, R., Paul, S., Gupta, A.K., Kachroo, P.L. and Bani, S. (1997) Synthesis and Biological Activities of Some 2-Substituted Phenyl-3-(3-alkyl/aryl-5,6-dihydro-s-triazolo[3,4-b][1,3,4]thiazolo-6-yl)-indoles. Indian Journal of Chemistry, 36, 707-710.

[15] Singh, H., Shukla, K.N., Dwivedi, R. and Yadav, L.D.S. (1990) Cycloaddition of 4-Amino-3-mercapto-1,2,4-triazole to Heterocumulenes and Antifungal Activity of the Resulting 1,2,4-Triazolo[3,4-c]-1,2-dithia-4,5-diazines. Journal of Agricultural \& Food Chemistry, 38, 1483-1486. http://dx.doi.org/10.1021/jf00097a011

[16] Kawsar, S.M.A., Islam, M.M., Chowdhury, S.A., Hasan, T., Hossain, M.K., Manchur, M.A. and Ozeki, Y. (2013) De- 
sign and Newly Synthesis of Some 1,2-O-isopropylidene- $\alpha$-D-glucofuranose Derivatives: Characterization and Antibacterial Screening Studies. Hacettepe Journal of Biology and Chemistry, 41, 195-206.

[17] Kawsar, S.M.A., Faruk, M.O., Rahman, M.S., Fujii, Y. and Ozeki, Y. (2014) Regioselective Synthesis, Characterization and Antimicrobial Activities of Some New Monosaccharide Derivatives. Scientia Pharmaceutica, 82, 1-20. http://dx.doi.org/10.3797/scipharm.1308-03

[18] Kabir, A.K.M.S., Matin, M.M. and Kawsar, S.M.A. (1998) Synthesis and Antibacterial Activities of Some Uridine Derivatives. Chittagong University Journal of Science, 22, 13-18.

[19] Kabir, A.K.M.S., Kawsar, S.M.A., Bhuiyan, M.M.R. and Hossain, S. (2003) Synthesis and Characterization of Some Uridine Derivatives. Journal of Bangladesh Chemical Society, 16, 6-14.

[20] Kawsar, S.M.A., Ferdous, J., Mostafa, G. and Manchur, M.A. (2014) A Synthetic Approach of D-Glucose Derivatives: Spectral Characterization and Antimicrobial Studies. Chemistry \& Chemical Technology, 8, 19-27.

[21] Kawsar, S.M.A., Kabir, A.K.M.S., Bhuiyan, M.M.R., Ferdous, J. and Rahman, M.S. (2013) Synthesis, Characterization and Microbial Screening of Some New Methyl 4,6-O-(4-methoxybenzylidene)- $\alpha$-D-glucopyranoside Derivatives. Journal of Bangladesh Academy of Sciences, 37, 145-158.

[22] Kawsar, S.M.A., Kabir, A.K.M.S., Manik, M.M., Hossain, M.K. and Anwar, M.N. (2012) Antibacterial and Mycelial Growth Inhibition of Some Acylated Derivatives of D-Glucopyranoside. International Journal of Bioscience, 2, 66-73.

[23] Kabir, A.K.M.S., Kawsar, S.M.A., Bhuiyan, M.M.R., Rahman, M.S. and Chowdhury, M.E. (2009) Antimicrobial Screening Studies of Some Derivatives of Methyl $\alpha$-D-Glucopyranoside. Pakistan Journal of Scientific and Industrial Research, 52, 138-142.

[24] Kabir, A.K.M.S., Kawsar, S.M.A., Bhuiyan, M.M.R. and Banu, B. (2008) Synthesis of Some New Derivatives of Methyl 4,6-O-cyclohexylidene- $\alpha$-D-glucopyranoside. Journal of Bangladesh Chemical Society, 21, 72-80.

[25] Kabir, A.K.M.S., Kawsar, S.M.A., Bhuiyan, M.M.R., Islam, M.R. and Rahman, M.S. (2004) Biological Evaluation of Some Mannopyranoside Derivatives. Bulletin of Pure \& Applied Sciences, 23, 83-91.

[26] Bauer, A.W., Kirby, W.M.M., Sherris, J.C. and Turck, M. (1966) Antibiotic Susceptibility Testing by a Standardized Single Disc Method. American Journal of Clinical Pathology, 45, 493-496.

[27] Miah, M.A.T., Ahmed, H.U., Sharma, N.R., Ali, A. and Miah, S.A. (1990) Antifungal Activity of Some Plant Extracts. Bangladesh Journal of Botany, 19, 5-10.

[28] McLaughlin, J.L. (1991) In: Hostettmann, K., Ed., Methods in Plant Biochemistry: Assays for Bioactivity, Vol. 1, Academic Press, London, 1-31.

[29] Loss, A. and Lutteke, T. (2015) Using NMR Data on GLYCOSCIENCES.de. In: Lütteke, T. and Frank, M., Eds., Glycoinformatics, Methods in Molecular Biology, Vol. 1273, Springer, New York, 87-95. http://dx.doi.org/10.1007/978-1-4939-2343-4 6

[30] Brauer, B., Pincu, M., Buch, V., Bar, I., Simons, J.P. and Gerber, R.B. (2011) Vibrational Spectra of $\alpha$-Glucose, $\beta$-Glucose, and Sucrose: Anharmonic Calculations and Experiment. The Journal of Physical Chemistry A, 115, 58595872. http://dx.doi.org/10.1021/jp110043k

[31] Kawsar, S.M.A., Khaleda, M., Asma, R., Manchur, M.A., Koide, Y. and Ozeki, Y. (2015) Infrared, ${ }^{1}$ H-NMR Spectral Studies of some Methyl 6-O-myristoyl- $\alpha$-D-glucopyranoside Derivatives: Assessment of Antimicrobial Effects. International Letters of Chemistry, Physics and Astronomy, 58, 122-136. http://dx.doi.org/10.18052/www.scipress.com/ILCPA.58.122

[32] Kawsar, S.M.A., Faruk, M.O., Mostafa, G. and Rahman, M.S. (2014) Synthesis and Spectroscopic Characterization of Some Novel Acylated Carbohydrate Derivatives and Evaluation of Their Antimicrobial Activities. Chemistry \& Biology Interface, 4, 37-47.

[33] Kawsar, S.M.A., Hasan, T., Chowdhury, S.A., Islam, M.M., Hossain, M.K. and Manchur, M.A. (2013) Synthesis, Spectroscopic Characterization and in Vitro Antibacterial Screening of Some D-Glucose Derivatives. International Journal of Pure and Applied Chemistry, 8, 125-135.

[34] Kawsar, S.M.A., Kabir, A.K.M.S., Bhuiyan, M.M.R., Siddiqa, A. and Anwar, M.N. (2012) Synthesis, Spectral and Antimicrobial Screening Studies of Some Acylated D-Glucose Derivatives. Rajiv Gandhi University of Health Sciences (RGUHS) Journal of Pharmaceutical Sciences, 2, 107-115.

[35] Kabir, A.K.M.S., Kawsar, S.M.A., Bhuiyan, M.M.R., Rahman, M.S. and Banu, B. (2008) Biological Evaluation of Some Octanoyl Derivatives of Methyl 4,6-O-cyclohexylidene- $\alpha$-D-glucopyranoside. The Chittagong University Journal of Biological Science, 3, 53-64.

[36] Kim, Y.M., Farrah, S. and Baney, R.H. (2007) Structure-Antimicrobial Activity Relationship for Silanols, a New Class of Disinfectants, Compared with Alcohols and Phenols. International Journal of Antimicrobial Agents, 29, 217-222. http://dx.doi.org/10.1016/j.ijantimicag.2006.08.036 
[37] Hunt, W.A. (1975) The Effects of Aliphatic Alcohols on the Biophysical and Biochemical Correlates of Membrane Function. Advances in Experimental Medicine and Biology, 56, 195-210. http://dx.doi.org/10.1007/978-1-4684-7529-6_9

[38] Judge, V., Narasimhan, B., Ahuja, M., Sriram, D., Yogeeswari, P., Clercq, E.D., Pannecouque, C. and Balzarini, J. (2013) Synthesis, Antimycobacterial, Antiviral, Antimicrobial Activity and QSAR Studies of N2-Acyl Isonicotinic Acid Hydrazide Derivatives. Medicinal Chemistry, 9, 53-76. http://dx.doi.org/10.2174/157340613804488404 